\title{
Some Wild Plants Consumed as Vegetables in Sanliurfa
}

\author{
Abdulhabip ÖZEL ${ }^{1}$ and İslim KOŞAR ${ }^{2}$ \\ 1. Dept. of Field Crops, Fac. of Agric., Harran Univ., Şanliurfa 63300, Turkey \\ 2. GAP Agricultural Research Inst., Şanliurfa 63300, Turkey
}

\begin{abstract}
This study was carried out to identify wild plants which are widely consumed as vegetables by local communities in Şanliurfa and neighboring provinces. The data were collected in different ways such as face to face interview with who collect these plants for directly consuming and marketing, and used for different purposes. As results of study, evaluation was done through data which were collected on characteristics of some plants usage fields, local and scientific names, and economic importance. Some species were determined (Gundelia tournefortii L., Ornithogalum narbonense L., Mentha pulegium L., Malva neglecta L., Nasturtium officinale R. Br., Anchusa azurea Miller., Arum dioscoridis Sm., Ferula orientalis L., Eryngium billardieri Delar., Capsella bursa-pastoris (L.) Medik. and Apium nodiflorum (L.) Lag. etc.) which are naturally grown and more intense in Şanlıurfa.
\end{abstract}

Key words: Wild plants, usage areas.

\section{Introduction}

Since ancient times, people have been trying to adapt to the natural conditions of natural life. People have always needed wild plants, both for health and food. Turkey has a rich plant diversity due to its geographical location, climate and ecological characteristics. The Southeastern Anatolia Region has about 3,500 plant species, of which about one third are endemic [1, 2]. In this region, the number of people living in rural areas is about $35 \%$ of the total population. The people of the region collected some wild plants, from the nature, which are used as food in various forms [3].

In this study, it was tried to introduce some wild plants grown in and around Şanliurfa province and consumed as vegetables in the region.

\section{Materials and Methods}

The area of Şanliurfa is $18.765 \mathrm{~km}^{2}$, with an average altitude of $518 \mathrm{~m}$. It has a wide plain; $60.4 \%$ plateau, $22.0 \%$ mountainous, $16.3 \%$ plain and 1.3\% high plateau character. Harran, Suruc and Viransehir plains are located in the south of Şanlıurfa. Karacadag

Corresponding author: Abdulhabip ÖZEL, ass. prof. Dr., research field: medicinal and aromatic plants breeding. is the highest point of the province with an elevation of 1,938 meters [4].

Şanlıurfa is under the influence of Mediterranean climate. The summers are warm and dry, while the winters are relatively mild. From south to north, the amount of precipitation increases. The average annual precipitation is around $384 \mathrm{~mm}$. The average annual temperature is $17.1{ }^{\circ} \mathrm{C}$, the highest temperature is $46.8^{\circ} \mathrm{C}$ and the lowest temperature is $-16.8^{\circ} \mathrm{C}$ [5].

The research was conducted between February 15, 2016 and May 15, 2016 in Şanlıurfa province and districts. Information was gathered from people who collected wild plants consumed as vegetables and sold them in markets, made face to face survey method. Thus, wild plants collected and consumed as vegetables by the local people in Şanliurfa province and its vicinity were identified and learned about how they were consumed. The areas where these plants are growing have been identified and photographed.

\section{Results and Discussion}

Local people use some wild plants that grow naturally, as vegetables directly, while others use them in more varied areas by drying or by soaking in salty water [1]. Wild plants are collected from land which is 
far from highways, there is no chemical waste, and from non-agricultural land. From March to May, wild plants are collected and sold.

Gundelia tournefortii L., is called as Kenger in Turkish [6, 7] (Fig. 1). Kenger is 40-50 cm height, thorny herbaceous plant, belongs to Asteraceae family. It is spiny compound inflorescences that contain cream, yellow, greenish, pink, purple or redish-purple petals. The stems are simple or little branched, short and thick. The leaves are skinny, whitish veined, feathered, stalkless. Kenger naturally grows in mountainous and arid regions. Kenger is known to have an effect on appetizing, gum strengthening, fatigue reliever, relieving kidney and bladder ailments, and has a preventive effect on stomach acid [7].

Underground young shoots of the plant are removed from the soil and consumed as vegetables. Different dishes are made from boiled shoots.

Ornithogalum narbonense L., is called as Akbandır in Turkish (Fig. 2). Akbandır [6] is 50-70 cm height, a herbaceous perennial flowering plant with underground bulbs, belonging to the Asparagaceae family. The stems are erect and the long leaves are fleshy and lance-shaped. The raceme is pyramidal, with hermaphrodite flowers. Each flower has a long bract, six star-shaped milky white petals bearing a pale green central vein, while the buds are oval, with longitudinal green and white stripes [7]. Young Akbandır plants are collected and consumed in various ways. The collected young plants are selected, washed and finely chopped. Then boil it until it softens with some water. Then, it is fried in oil with some salt and pepper. It is served with yogurt.

Mentha pulegium L., is called as Yarpuz in Turkish [6] (Fig. 3). Yarpuz is $80-110 \mathrm{~cm}$ height, a species of flowering plant in the family Lamiaceae. The leaves include very strong fragrance similar to spearmint. Yarpuz is a traditional culinary herb and folk remedy. The essential oil of Yarpuz is used in aromatherapy. It is usually found in wetlands and on water borders [7]. Young Yarpuz plants are consumed as green vegetables beside the meals.

Malva neglecta L., called as ebegömeci, develik, gömeç, kömeç and tolik by local people in Turkey [6] (Fig. 4). Leaves and flowers of $M$. neglecta have a wide range of usage area. In the traditional medicine,

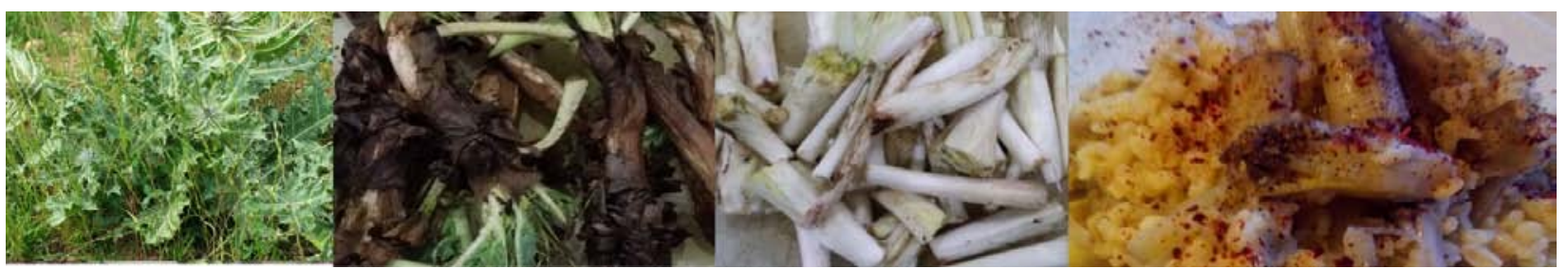

Fig. 1 Gundelia tournefortii L., Kenger.
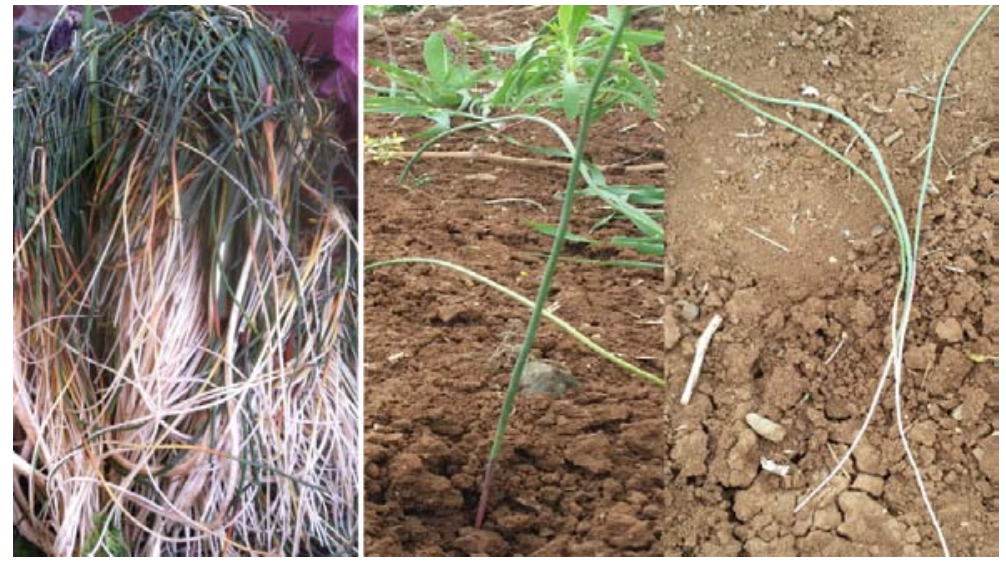

Fig. 2 Ornithogalum narbonense L., Akbandır. 


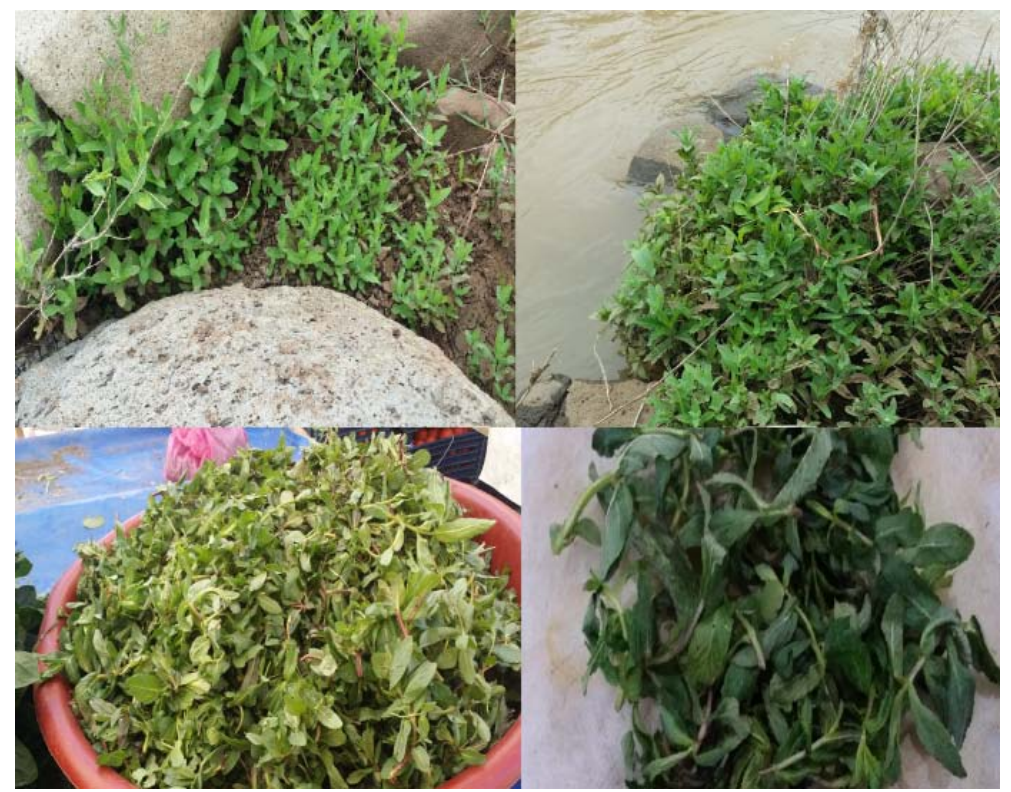

Fig. 3 Mentha pulegium L., Yarpuz.

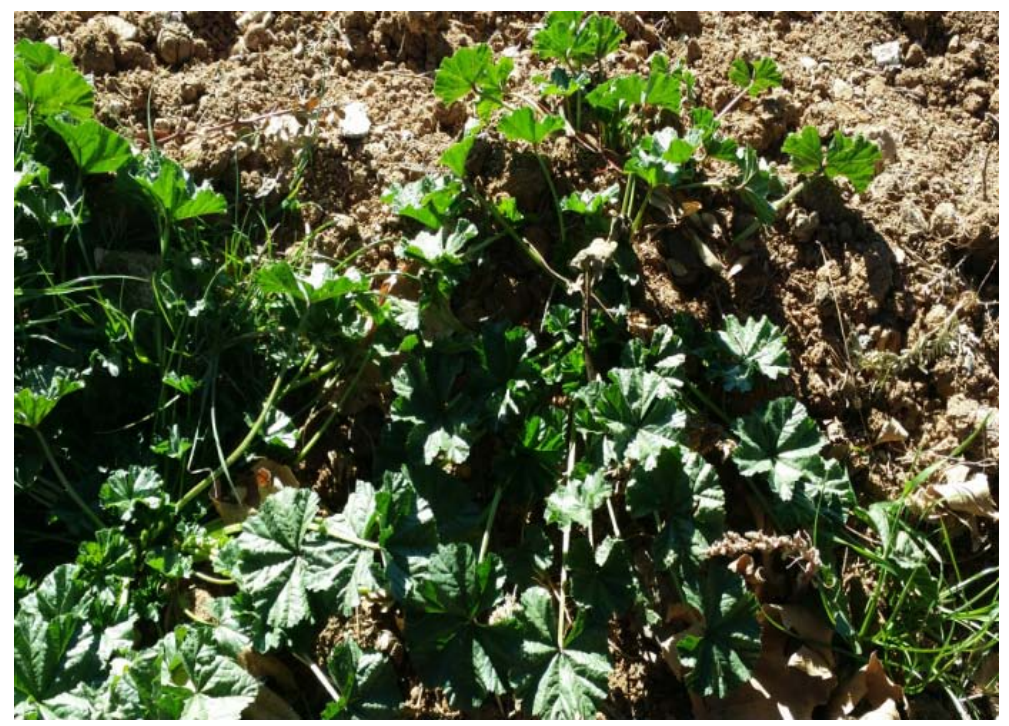

Fig. 4 Malva neglecta L., Ebegömeci.

it is used for the constipation, sore throat, women sterility, wound, hemorrhoids, miscarriage swellings, rheumatic pain, stomachache, abdominal pain, abscess, renal diseases, ease of cough, throat infection, peptic ulcer, common cold, stomachache, bronchitis, indigestion [7].

Young ebegömeci plants are collected and consumed in various ways. The young plants are selected, washed and finely chopped. Then, it is fried in oil with some salt and pepper. And then it is served in different way.
Nasturtium officinale R. Br., is called as Suteresi and Tuzik by local people in Turkey [7] (Fig. 5). Suteresi is a perennial herbaceous plant, a species of flowering plant in the family Brassicaceae. Suteresi is a rapidly growing, aquatic or semi-aquatic, perennial plant and one of the oldest known leaf vegetables [7]. Young Suteresi plants are collected and consumed as green vegetables beside the meals.

Capsella bursa-pastoris (L.) Medik., is called as Çoban çantası and Nanecik by local people in Turkey [6] (Fig. 6). It is an annual herbaceous plant in the 
family Brassicaceae, 40-50 cm height. It is considered a common weed in many parts of the world [7]. Young plants grow from a rosette of lobed leaves at the base. These leaves are collected and consumed in various ways.

Leaves are consumed as green vegetables beside the meals or fried in oil with some salt and pepper. And then it is served in different ways.

Anchusa azurea Miller, is called as Sığırdili and Güriz by local people in Turkey [6] (Fig. 7). It is a species of flowering plant in the family Boraginaceae, a hairy perennial plant which reaches $50 \mathrm{~cm}$ in height. It has straight lance shaped leaves and small tubular flowers of bright blue. This species is well-known as a noxious weed [7]. The locals eat the young stems consumed in various ways. The young plants are selected, washed and finely chopped. Then, it is boiled and fried in oil with some salt and pepper. And then it is served in different ways.

As results of study, evaluation was done through data which were collected on characteristics of some plants usage fields, local and scientific names, and economic importance. Some species were determined (Gundelia tournefortii L., Ornithogalum narbonense L., Mentha pulegium L., Malva neglecta L., Nasturtium officinale R. Br., Anchusa azurea Miller., Arum dioscoridis Sm., Ferula orientalis L., Eryngium billardieri Delar., Capsella bursa-pastoris (L.) Medik.,

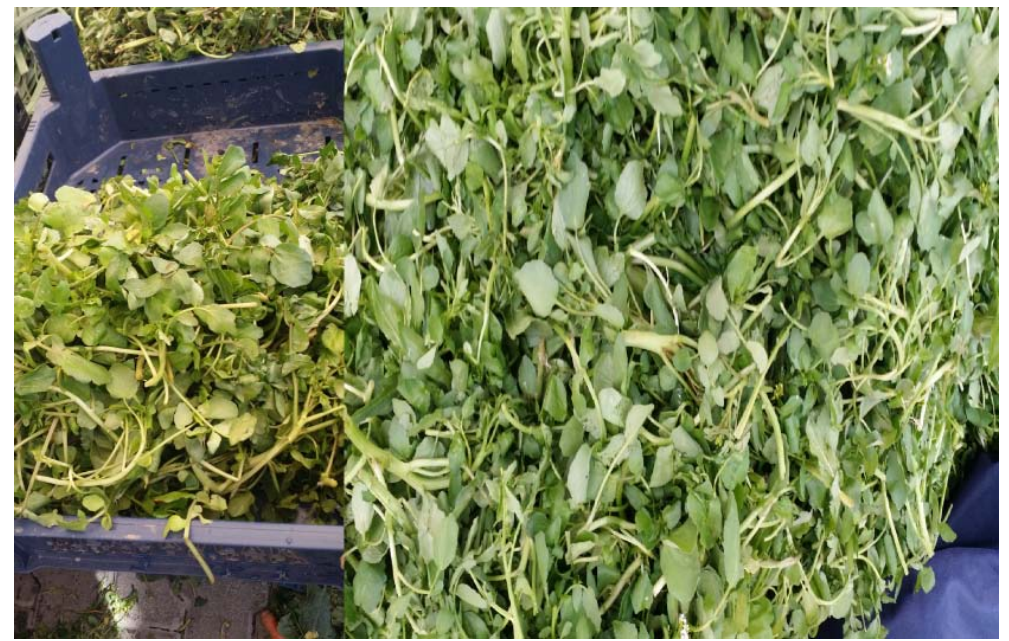

Fig. 5 Nasturtium officinale R. Br., Suteresi.

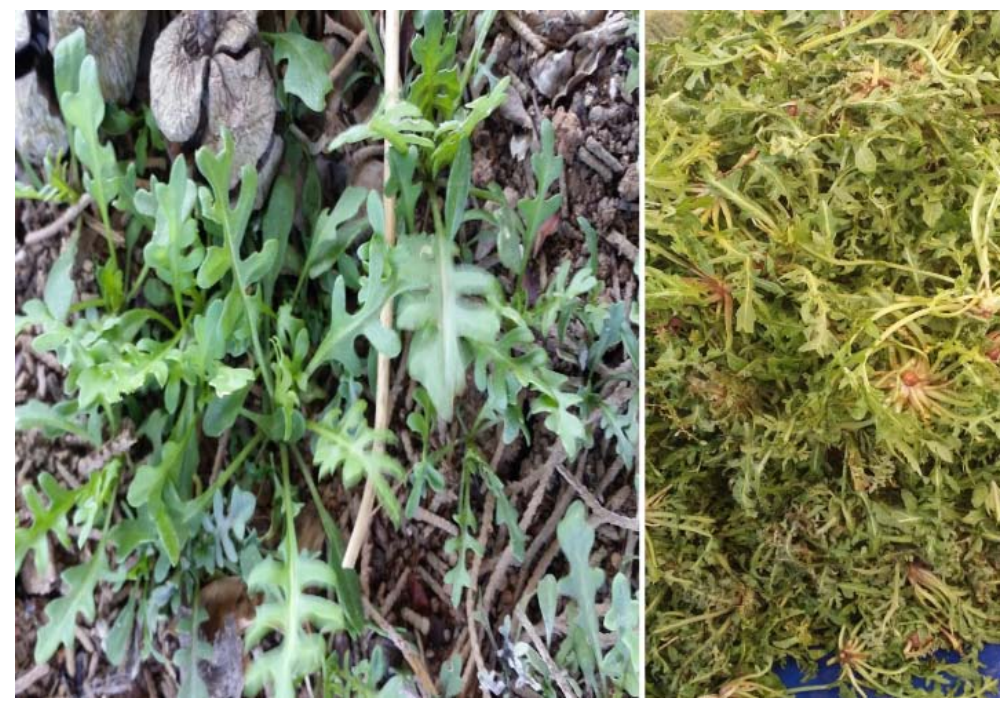

Fig. 6 Capsella bursa-pastoris (L.) Medik. 


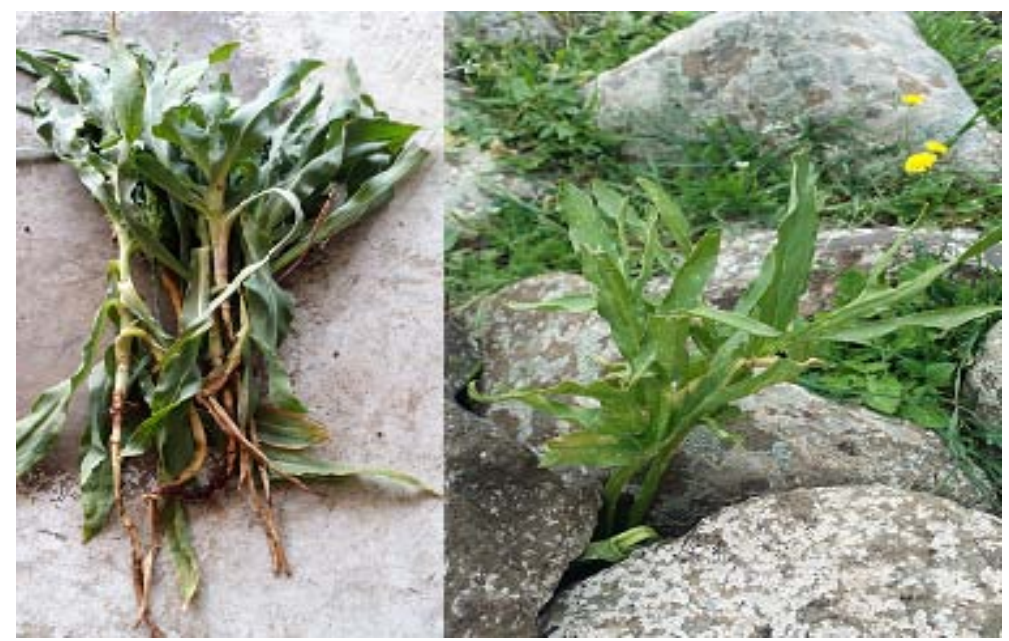

Fig. 7 Anchusa azurea Miller, Güriz.

and Apium nodiflorum (L.) Lag. etc.) which are naturally grown and more intense in Şanlıurfa.

\section{References}

[1] Kaya, Z., Kün, E., and Güner, A. 1998. Türkiye Bitki Genetik Çeşitliliğinin Yerinde (in situ) Korunması Ulusal Planı. Çevre Bakanlığı, Çevre Koruma Genel Müdürlüğü, Bitki Koruma ve Erozyonla Mücadele Daire Başkanlığı, $96 \mathrm{s.}$

[2] Sezik, E. 1990. "GAP ve Tabiatın Yok olması." TÜBİTAK Bülteni 7: 1-2.
[3] Özel, A. 1999. Güneydoğu Anadolu Bölgesi Tibbi ve Aromatik Bitkileri. GAP I. Tarım Kongresi, HR.Ü. Ziraat Fakültesi, 26-28 Mayıs 1999: 869-76, Şanlıurfa.

[4] Anonymuse. 1971. Urfa ili Toprak Kaynağı Envanter raporu. Topraksu Genel Müdürlüğü Yayınları No. 224, Ankara. www.sanliurfa.gov.tr.

[5] Anonymouse. 2016. Meteoroloji Genel Müdürlüğü, www.mgm.gov.tr.

[6] Baytop, T. 1997. Türkçe Bitki Adlar Sözlüğü. Türk tarih kurumu basımevi, ISBN: 975-16-0542-3, 512 s.

[7] Baytop, T. 1999. Türkiye'de Bitkiler ile Tedavi. Nobel KITAPEVİ, ISBN: 975-420-021-1, 480 s. 